\title{
Mechanical and mineralogical properties of natural hydraulic lime-metakaolin mortars in different curing conditions
}

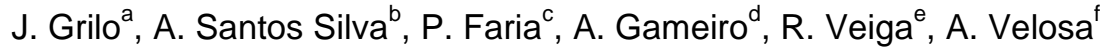

a. National Laboratory for Civil Engineering, Av. do Brasil, 101, Lisbon, Portugal, jonegrilo@hotmail.com

b. National Laboratory for Civil Engineering, Av. do Brasil, 101, Lisbon, Portugal, ssilva@Inec.pt

c. Department of Civil Engineering, NOVA University of Lisbon, 2829-516 Caparica, Portugal, paulina.faria@fct.unl.pt

d. National Laboratory for Civil Engineering, Av. do Brasil, 101, Lisbon, Portugal, andregameiro24@gmail.com

e. National Laboratory for Civil Engineering, Av. do Brasil, 101, Lisbon, Portugal, rveiga@Inec.pt

f. Department of Civil Engineering, Geobiotec, University of Aveiro, Aveiro, avelosa@ua.pt

\section{Abstract}

This paper investigates the mechanical and mineralogical characteristics of natural hydraulic lime NHL3.5 (NHL) mortars with different \% of lime replacement by metakaolin (MK) under different laboratory and natural marine curing conditions.

Tests were conducted at different curing ages, using compressive and flexural strength tests and thermogravimetric and X-ray diffraction techniques.

NHL mortars cured at high humidity levels in natural and artificial environments present interesting results and some could be used in old masonries repair.

The incorporation of MK improves the NHL mortars strength, being this increase mostly associated to the pozzolanic reaction.

\section{Keywords}

Hydraulic mortars; NHL3.5; metakaolin; curing conditions; characterization; XRD; TGDTA;

Notation: $\mathrm{A}-\mathrm{Al}_{2} \mathrm{O}_{3}, \mathrm{C}-\mathrm{CaO}, \overline{\mathrm{C}}-\mathrm{CO}_{2}, \mathrm{H}-\mathrm{H}_{2} \mathrm{O}, \mathrm{S}-\mathrm{SiO}_{2}$ 
Grilo, J.; Santos Silva, A.; Faria, P.; Gameiro, A.; Veiga, R.; Velosa, A. Mechanical and mineralogical properties of natural hydraulic lime-metakaolin mortars in different curing conditions. Construction and Building Materials, v. 51, p. 287-294, 2014.

\section{Introduction}

Early civilizations, namely the Greeks and Romans, produced limes to employ in mortars for construction. The durability of these mortars is recognized worldwide, even in buildings exposed to water and is mainly attributed to the use of natural earthmaterials of volcanic origin (pozzolans), or to artificial reactive materials, as an addition or as a partial substitution for air lime or sand [1-3]. This knowledge was lost for centuries, only to be revived in the $18^{\text {th }}$ century with Smeaton's rediscovery of the hydraulic properties of a limestone from Portland in England. This material was the base of new types of inorganic binders, known as hydraulic binders, of which artificial Portland cement (PC) was a successor, becoming the binder most used worldwide today. The properties of the PC were the reason for the decline of the lime technology [4-8].

Nowadays, it is well known that PC mortars present several problems regarding their use in restoration of historical structures containing lime mortars. Some of the main problems are associated to their incompatibility in terms of mechanical, physical and chemical properties [8,9]. To prevent the damage and deterioration of these historic structures it is recommended that repairs be carried out by lime-based mortars, which encompasses the use of hydraulic mortars with low strength capacity and without soluble salt contamination problems.

The recent version of European standard for lime binders defines three classes of limes with hydraulic properties: natural hydraulic (NHL), formulated (FL) and hydraulic $(\mathrm{HL})$, according to the constitutive raw materials and the presence or absence of additions. The NHL limes are divided in three classes according to the compressive strength developed after 28 days curing and to the $\mathrm{Ca}(\mathrm{OH})_{2}$ content: NHL2, NHL3,5 and NHL5 $[10,11]$.

The use of hydraulic lime, that also goes back to antiquity with the use of limes with various levels of hydraulicity, has been revived in the past few years, especially when the conservation of historical buildings is pursued. In particular, the natural 
Grilo, J.; Santos Silva, A.; Faria, P.; Gameiro, A.; Veiga, R.; Velosa, A. Mechanical and mineralogical properties of natural hydraulic lime-metakaolin mortars in different curing conditions. Construction and Building Materials, v. 51, p. $287-294,2014$.

hydraulic limes seem to have the possibility to be an adequate choice due to their improved compatibility with old masonry, by having low shrinkage, resistance to salt and frost damage, in comparison with PC or other hydraulic lime mortars, as well as higher deformability and water vapour permeability $[5,9,12]$.

$\mathrm{NHL}$ are obtained by calcining mixtures of clayish or siliceous limestones at temperatures below the clinkering point, before being reduced to a powder by adding controlled amounts of water. A fundamental characteristic of these lime mortars is the fact that they have two hardening phases: a hydraulic phase, based on its hydration, resulting in the formation of calcium and calcium-aluminum silicate hydrates, and another developed during the $\mathrm{CO}_{2}$ contact, and designated as carbonation $[11,13,14]$.

These recent $\mathrm{NHL}$, defined and formulated in accordance to the actual version of standard EN 459-1 [10], are relatively new in the market and their properties are not yet well studied, namely in terms of their use with pozzolanic materials. At this respect, MK is known by improving the durability characteristics of lime and cement mortars $[15,16]$

Pozzolans are composed by siliceous and silico-aluminous substances, which when hydrated do not harden with water; however, when they are powdered and in presence of calcium hydroxide they react to form new compounds, such as silicates and calcium aluminate hydrates, with hydraulic properties $[1,17,18]$.

Besides the influence of the addition of pozzolanic materials the mortars' curing conditions are also important, namely the definition of their use once it is known that the curing of lime-pozzolan mortars benefits from a humid long lasting curing [15]. A dry or a humid curing condition propitiates the development of different setting and hardening reactions, which will influence the mortars porosity, strength and microstructure properties. As reported elsewhere, not so humid curing conditions (dry but not too much) favors the carbonation reaction, while humid curing favors hydration reaction [19-21]. 
The results that will be presented are part of a wide study aiming at the characterization of an NHL3.5 of Portuguese production, with and without MK incorporation, as lime substitution, in three different curing conditions [22]. The curing conditions used include the exposition in an experimental site at Atlantic Ocean west coast (Cabo Raso near Cascais Village), in order to compare it with laboratory controlled conditions at two different relative humidity $(\mathrm{RH})$ testing conditions $(65 \%$ and $95 \%)$ at the same temperature $\left(20^{\circ} \mathrm{C}\right)$.

This paper focuses on the mechanical and mineralogical characterization regarding the influence of the MK incorporation and curing conditions on the behaviour of NHL-based mortars. These results will be particularly useful in the establishment of both adequate curing conditions and metakaolin content proportions regarding NHL3.5 mortars to optimize their formulation to use in new masonry renders or in mortars designed for historical conservation purposes.

\section{Materials}

The mortars were prepared with a commercial Portuguese natural hydraulic lime NHL3.5 [10] (NHL) and a washed and well graded siliceous river sand. The NHL content was maintained (NHL mortar with a volumetric binder:aggregate ratio of 1:3) or replaced by $10 \%$ (NHL_10MK mortar) or 20\% (NHL_20MK mortar) (wt.\%) of a commercial metakaolin (ARGICAL M1200S - MK). Table 1 presents the loose bulk density of the materials employed in the mortars formulation determined according to the European Standard EN 1097-3:2002 [23].

The chemical compositions (major elements) of $\mathrm{NHL}$ and MK was carried out by Xray fluorescence analysis (XRF) using a Panalytical Axios X-ray fluorescence spectrometer with CrKa radiation, being these results presented in Table 2. The pozzolanic reactivity of the MK is also presented. The pozzolanic activity was determined by Chapelle test method [24], and comparing the value obtained with other 
artificial pozzolanic materials, like rice husk ash, biomass fly ash or coal fly ash [25], it is expected a high reactivity wit NHL.

The identification of mortar mixes, percentage of lime weight substitution by MK, weight ratios and water/binder ratio are shown in Table 3.

Table 1 - Loose bulk density of materials used in mortar preparation.

\begin{tabular}{|c|c|}
\hline \multicolumn{2}{|c|}{ Loose bulk density $\left.\mathbf{( k g} / \mathbf{m}^{\mathbf{3}}\right)$} \\
\hline MK & 0.294 \\
\hline NHL3,5 & 0.846 \\
\hline Sand mixture & 1.463 \\
\hline
\end{tabular}

Table 2 - Chemical composition (in wt. \%) of materials used as binder in mortar preparation and pozzolanic reactivity.

\begin{tabular}{|c|c|c|c|c|c|c|c|c|c|c|c|c|c|}
\hline Material & $\mathrm{SiO}_{2}$ & $\mathrm{Al}_{2} \mathrm{O}_{3}$ & $\mathrm{Fe}_{2} \mathrm{O}_{3}$ & $\mathrm{MnO}$ & $\mathrm{MgO}$ & $\mathrm{Na}_{2} \mathrm{O}$ & $\mathrm{K}_{2} \mathrm{O}$ & $\mathrm{TiO}_{2}$ & $\mathbf{P}_{2} \mathrm{O}_{5}$ & $\mathbf{S O}_{3}$ & $\mathbf{C a O}$ & LOI* & $\begin{array}{c}\text { Pozzolanic } \\
\text { activity } \\
(\mathbf{m g} \mathbf{C H} / \mathbf{g} \mathbf{M K})\end{array}$ \\
\hline $\mathrm{MK}$ & 54.39 & 39.36 & 1.75 & 0.01 & 0.14 & - & 1.03 & 1.55 & 0.06 & - & - & 1.90 & 1320 \\
\hline $\mathrm{NHL}$ & 5.70 & 1.84 & 1.22 & 0.02 & 1.00 & 0.08 & 0.49 & 0.14 & 0.03 & 1.00 & 62.00 & 26.00 & - \\
\hline
\end{tabular}

*LOI. - Loss on ignition

Table 3 - Mortar mixes identification, composition and flow table consistency.

\begin{tabular}{|c|c|c|c|c|c|}
\hline \multirow{2}{*}{$\begin{array}{c}\text { Sample } \\
\text { identification }\end{array}$} & $\begin{array}{c}\text { MK } \\
\text { substitution } \\
\text { [\%] }\end{array}$ & \multicolumn{3}{|c|}{ Weight ratio } & \multirow{2}{*}{$\begin{array}{c}\text { Consistency } \\
\text { [mm] }\end{array}$} \\
\cline { 3 - 5 } & 0 & NHL:MK:Aggregate & NHL+MK:Aggregate & Water/binder & \\
\hline NHL & 10 & $1: 0.1: 5.5$ & $1: 5$ & 1.1 & $152 \pm 1$ \\
\hline NHL_10MK & 10 & $1: 5$ & 1.1 & $149 \pm 2$ \\
\hline NHL_20MK & 20 & $1: 0.2: 6$ & $1: 5$ & 1.1 & $143 \pm 1$ \\
\hline
\end{tabular}

The mineralogical compositions of the raw materials (Figure 1) were obtained on a Philips PW3710 X-ray diffractometer, with $35 \mathrm{kV}$ and $45 \mathrm{~mA}$, using Fe-filtered CoKa radiation of wavelength $\lambda=1.7903 \AA$. Diffractograms were recorded from $3^{\circ}$ to $74^{\circ} 2 \theta$, at an angular speed of $0.05^{\circ} 2 \theta \mathrm{s}^{-1}$. The crystalline phases were identified by comparison with the International Centre for Diffraction Data Powder Diffraction Files (ICDD PDF). 
In the $\mathrm{NHL}$ the main mineralogical phases present are calcite $(\mathrm{C} \overline{\mathrm{C}})$, portlandite $(\mathrm{CH})$ and larnite $\left(\mathrm{C}_{2} \mathrm{~S}\right)$. Other minor phases are also present which include quartz $\left(\mathrm{SiO}_{2}\right)$, tricalcium aluminate $\left(\mathrm{C}_{3} \mathrm{~A}\right)$ and bassanite $\left(\mathrm{CaSO}_{4} \cdot 0,5 \mathrm{H}_{2} \mathrm{O}\right)$. The $\mathrm{MK}$ diffractogram is characterized by a broad band between 20 and $40{ }^{\circ} 2 \theta$, which is correlated to the existence of amorphous compounds that are responsible for the high MK pozzolanic character. Some minerals phases are also present in MK, which include quartz, muscovite $\left(\mathrm{KAl}_{3} \mathrm{Si}_{3} \mathrm{O}_{10}(\mathrm{OH})_{2}\right)$ and anatase $\left(\mathrm{TiO}_{2}\right)$. The aggregate used is of quartz-siliceous nature, mainly composed by quartz and some potassium feldspar $\left(\mathrm{KAISi}_{3} \mathrm{O}_{8}\right)$.

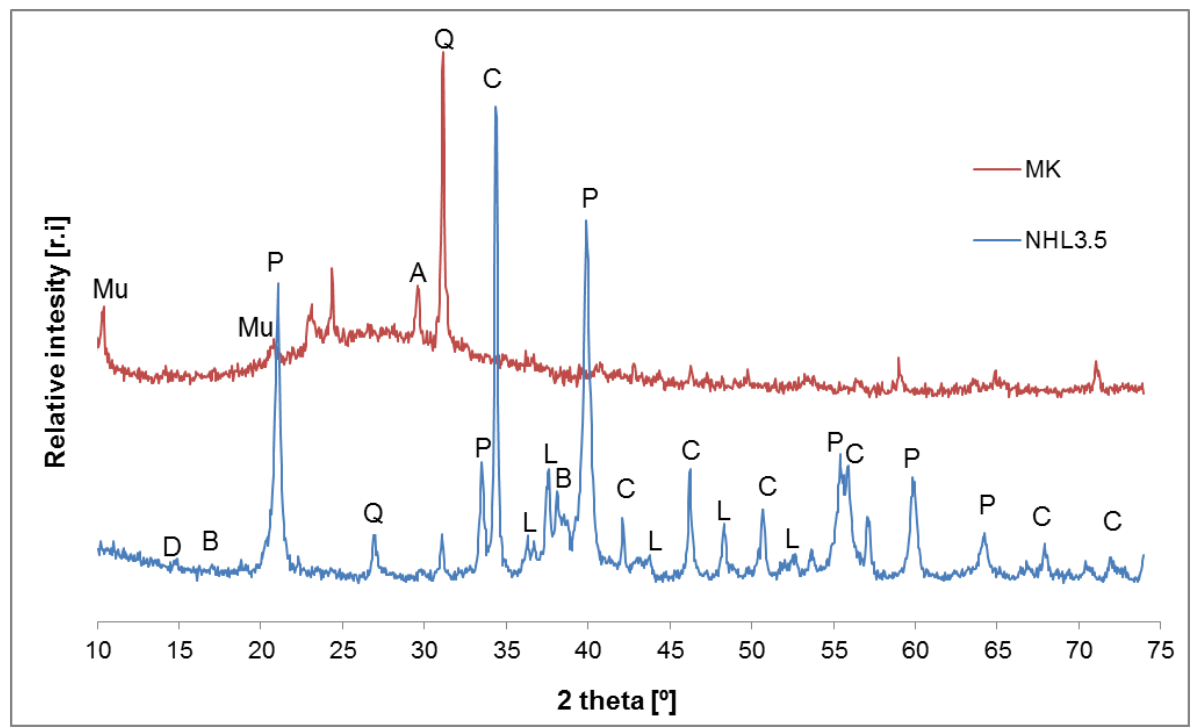

Fig. 1 - XRD patterns of the materials employed in the mortars manufacture. Notation: P - CH; C - C $\bar{C}$; L - $\mathrm{C}_{2} \mathrm{~S}$; Mu - Muscovite; B - Bassanite; D - $\mathrm{C}_{3} \mathrm{~A}$; Q-Quartz; A - Anatase;

In order to determine the portlandite and calcite contents of NHL, the TG-DTA analysis (Figure 2) was performed in a TG-DTA analyser, under argon atmosphere, with heating rate of $10^{\circ} \mathrm{C} / \mathrm{min}$, from room temperature to $1000^{\circ} \mathrm{C}$. Free portlandite content was determined from the mass loss in the range of $380-500^{\circ} \mathrm{C}\left(\mathrm{ML}_{\left(380-500^{\circ} \mathrm{C}\right)}\right)$, corresponding to portlandite dehydroxilation region $(\mathrm{DH})$, while the calcite content 
present in the lime sample was attained from the mass loss in the range of $550-850^{\circ} \mathrm{C}$ $\mathrm{ML}_{\left(500-850^{\circ} \mathrm{C}\right)}$, which corresponds to the $\mathrm{CO}_{2}$ release of carbonates (DC) (Figure 2).

Taking into account the TG results, the contents of free portlandite $\left(\mathrm{CHf}_{\text {lime }}\right)$ and calcite $\left(\mathrm{CC}_{\text {lime }}\right)$ were determined by equations 1 and 2 :

$\mathrm{CHf}_{\text {lime }}=\mathrm{ML}_{\left(380-500^{\circ} \mathrm{C}\right)} \times \mathrm{k}_{1}$

[Equation 1]

$\mathrm{CC}_{\text {lime }}=\mathrm{ML}_{\left(500-850^{\circ} \mathrm{C}\right)} \times \mathrm{k}_{2}$

[Equation 2]

being, the constants $\mathrm{k}_{1}$ and $\mathrm{k}_{2}$ the molar masses quotients of $\mathrm{CO}_{2}, \mathrm{Ca}(\mathrm{OH})_{2}, \mathrm{CaCO}_{3}$ and $\mathrm{H}_{2} \mathrm{O}$ in accordance of: $\mathrm{k}_{1}=\mathrm{MM}\left(\mathrm{Ca}(\mathrm{OH})_{2}\right) / \mathrm{MM}\left(\mathrm{H}_{2} \mathrm{O}\right)$ and $\mathrm{k}_{2}=\mathrm{MM}\left(\mathrm{CaCO}_{3}\right) / \mathrm{MM}$ $\left(\mathrm{CO}_{2}\right)$

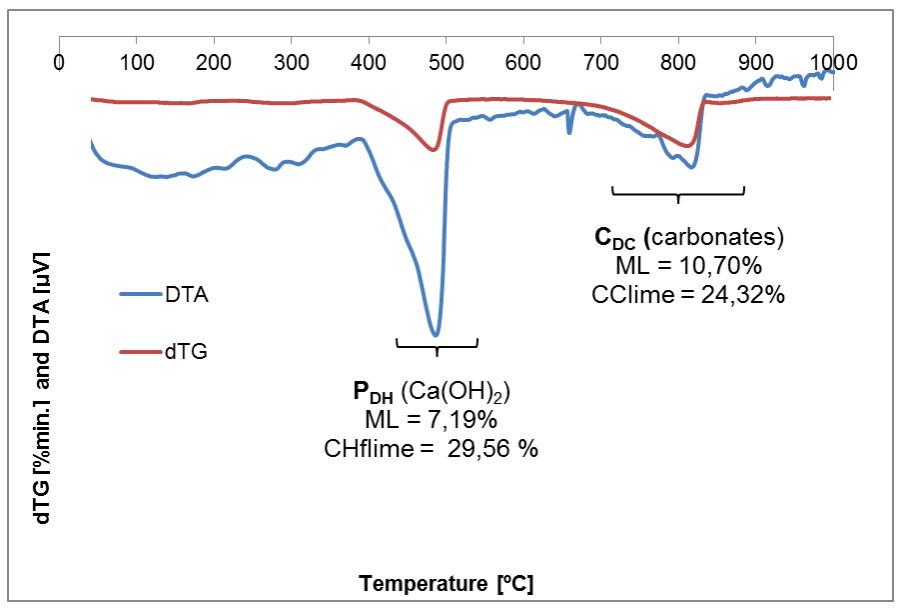

Fig. 2 - dTG and DTA curves for NHL, showing the characteristic regions for portlandite dehydration $-\mathrm{P}_{\mathrm{DH}}$ - and the carbonates decomposition - $\mathrm{C}_{\mathrm{DC}}$.

According to the TG results obtained, the NHL presents a relatively high calcite content which is attributed to lime carbonation.

\section{Mortars' mixture and curing conditions}

The mixing method was used for all mortars and based but including some adjustments to the EN 1015-2:1998/A1:2006 [26] procedure. The amount of water to achieve a comparable consistency, corresponding to a workability of approximately $150 \pm 10 \mathrm{~mm}$, was added in the first seconds of mixing; mechanical mixing went on for 150 seconds; the borders were scraped and the mixing continued for another 30 
seconds. The flow table consistency was determined based on EN 10153:1999/A2:2006 [27] and the average value and standard deviation for each mortar is presented in Table 3.

Mortars were cast in metallic prismatic moulds of $40 \times 40 \times 160\left(\mathrm{~mm}^{3}\right)$ and conditioned inside polyethylene bags for initial curing with high $\mathrm{RH}$. At the $2^{\text {nd }}$ day of curing, mortar samples were demoulded and continued inside the bags until completing 7 days. After this period they were placed in three different curing conditions:

- a natural exposure marine site (M), close to the Atlantic ocean coast (Guincho, close to Cascais village, Portugal), where prisms are exposed since February to natural salt water spray and to salt fog conditions. In terms of Portuguese climate, this was the best testing period since coincided with the end of winter (Table 4);

- curing in high humidity test conditions $(\mathrm{H})$, in a climatic chamber with a relative humidity $(\mathrm{RH})$ of $95 \pm 5 \%$ and temperature $(\mathrm{T})$ of $20 \pm 3^{\circ} \mathrm{C}$;

- standard curing conditions (S) normally used for lime mortars. This condition was made in a laboratory conditioned room with $\mathrm{RH}$ of $65 \pm 5 \%$ and $\mathrm{T}=20 \pm 3^{\circ} \mathrm{C}$.

All mortars were tested at 28,90 and 180 days of curing age.

Table 4 - Average temperatures and relative humidity values of curing period in $M$ curing condition.

\begin{tabular}{|c|c|c|c|c|c|c|}
\hline & February & March & April & May & June & July \\
\hline T [ $\left.{ }^{\circ} \mathbf{C}\right]$ & $10.3 \pm 3.9$ & $14.6 \pm 4.1$ & $13.3 \pm 2.4$ & $16.7 \pm 2.9$ & $19.2 \pm 3.8$ & $18.5 \pm 2.1$ \\
\hline RH [\%] & $60.0 \pm 16.7$ & $62.0 \pm 19.5$ & $73.2 \pm 12.3$ & $75.4 \pm 13.4$ & $69.0 \pm 18.5$ & $75.2 \pm 11.0$ \\
\hline
\end{tabular}

\section{Experimental}

\subsection{Flexural and compressive strength tests}

One day before testing, the samples were placed during $24 \mathrm{~h}$ in the standard curing condition in order to stabilize their internal humidity. The strength tests were 
Grilo, J.; Santos Silva, A.; Faria, P.; Gameiro, A.; Veiga, R.; Velosa, A. Mechanical and mineralogical properties of natural hydraulic lime-metakaolin mortars in different curing conditions. Construction and Building Materials, v. 51, p. $287-294,2014$.

done according the European standard EN 1015-11:1999/A1:2006 [28]. Flexural (FS) and compressive strengths (CS) were obtained using a universal forces Zwick Z050 with a $2 \mathrm{kN}$ load cell and velocity of $0.2 \mathrm{~mm} / \mathrm{min}$ for flexural test and a load cell of $50 \mathrm{kN}$ and a velocity of $0.7 \mathrm{~mm} / \mathrm{min}$ for compressive test. The compressive strength test was made on the half prisms obtained after the flexural tests.

\subsection{XRD and TG-DTA tests}

In order to avoid the influence of different humidity levels in the mineralogical composition, the samples were previously dried in oven at $40^{\circ} \mathrm{C}$ during 24 hours.

\subsubsection{X-ray diffraction analysis (XRD)}

The samples for XRD analysis were disaggregated with a rubber hammer in order to avoid breaking the sand grains, being the material afterwards sieved in a $106 \mu \mathrm{m}$ mesh in order to obtain a binder enriched fraction.

X-ray diffractograms were collected by the same process described in section 2 .

\subsubsection{Thermogravimetric and differential thermal analysis (TG-DTA)}

The mortar samples to be analysed by TG-DTA were ground up to $106 \mu \mathrm{m}$ grain size. The procedure adopted for mortars samples analysis was the same that was previously described in section 2 .

\section{Results and discussion}

\subsection{Mechanical results}

Figure 2 shows the flexural and compressive strength results obtained in the different curing conditions employed. A global analysis reveals that mortars in humid curing conditions present the highest values of FS. The mortars evolution with ageing did not present a regular pattern, except for the case of NHL mortars without MK that showed an increase in their FS values from 28 to 180 days. 
Relatively to CS values the NHL mortars cured in marine or humid condition present the highest values. This observation can be justified by the high humidity access in these conditions that promotes the $\mathrm{NHL}$ hydration reaction, and the mechanical strength.

MK incorporation results in a clear improvement of mortars strength. Again, the curing conditions with humidity access (humid and marine) present the highest CS and generally also FS values, independently of the testing age. An obvious explanation for this behavior is the less favorable hydration conditions in the standard curing compared to the other two conditions.

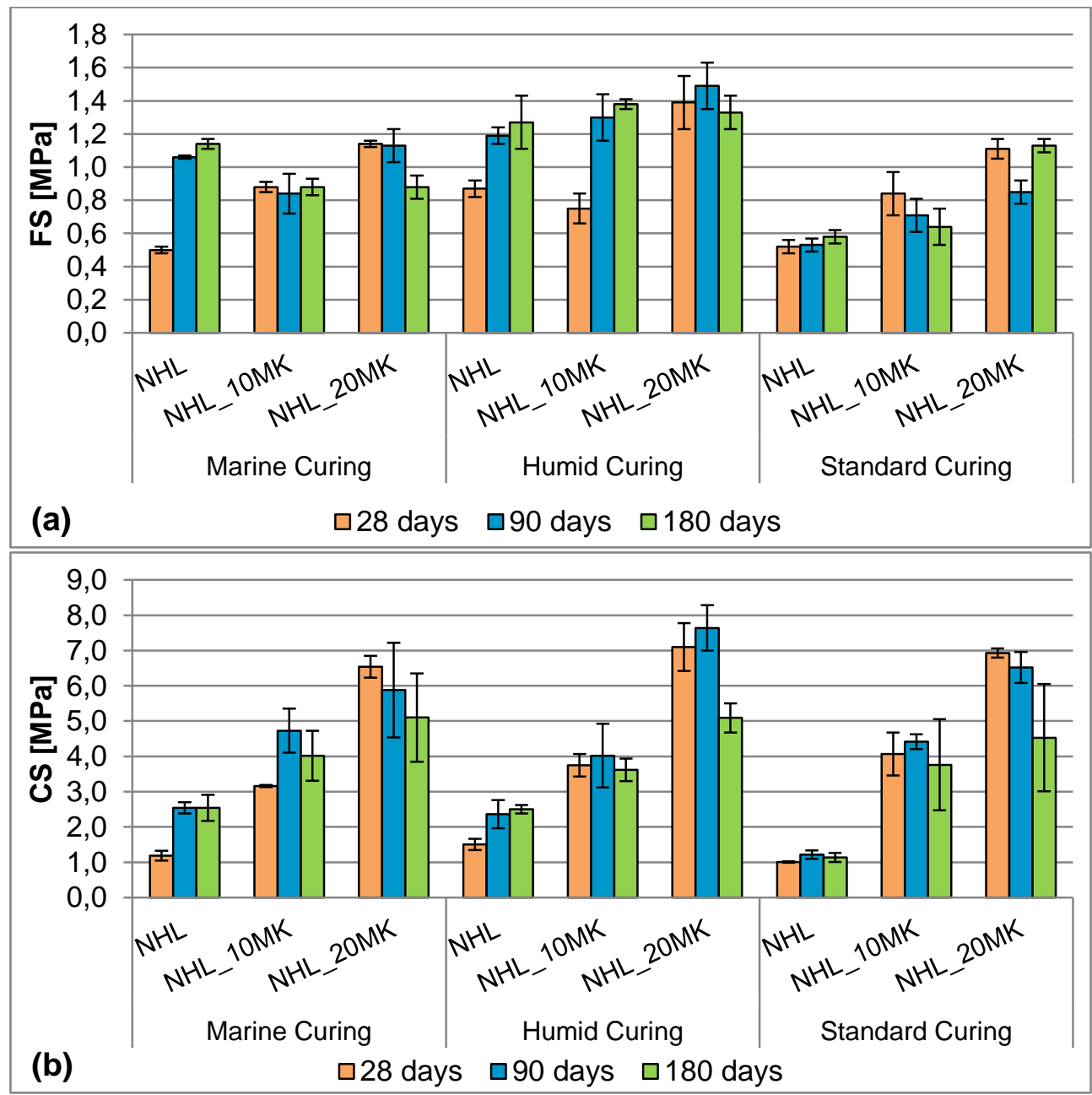

Fig. 3 - Mechanical results of all mortars in each curing; (a) flexural strength (FS) and (b) compressive strength (CS). 


\subsection{XRD results}

Table 5 presents the mineralogical composition of the different NHL mortars cured in marine, humid and standard curing conditions. For representative purposes, Figures 4 present the diffractograms of the samples tested in marine curing condition.

In all curing conditions the main crystalline phase present is calcite, which seems to indicate that carbonation was the dominant reaction. Besides calcite the other phases present are portlandite, larnite, ettringite $\left(\mathrm{Ca}_{6} \mathrm{Al}_{2}\left(\mathrm{SO}_{4}\right)_{3}(\mathrm{OH})_{12}\left(\mathrm{H}_{2} \mathrm{O}\right)_{26}\right)$, tetracalcium monocarboaluminate $\left(\mathrm{C}_{4} \mathrm{~A} \overline{\mathrm{C}} \mathrm{H}_{11}\right)$, tetracalcium aluminate hydrate $\left(\mathrm{C}_{4} \mathrm{~A} \mathrm{H}_{13}\right)$, vaterite $\left(\mathrm{CaCO}_{3}\right)$ and quartz $\left(\mathrm{SiO}_{2}\right)$. With exception of portlandite and ettringite, the other hydrated phases detected are mainly related with the pozzolanic reaction between NHL and MK.

One of the main differences between mortars with and without MK is the presence of vaterite in mortars with $\mathrm{MK}$, a polymorph of $\mathrm{CaCO}_{3}$, which seems to be formed due to the dissolution-precipitation of carbonates, its formation being higher with MK increase. Some authors refer that vaterite could be a precursor phase of calcite formation, which is hampered due to lower $\mathrm{CO}_{2}$ diffusion in MK mortars [29].

Contrary to what was expected in the marine curing, chlorides, free or combined, normally associated to natural marine environment, are not present. This fact, in view of the sea water proximity, indicates that it could be removed by rain washing over it.

Carbonation reaction develops over time, which is confirmed by portlandite and calcite proportions. This evolution is also followed by hydration reaction development, since at 180 days larnite is not present anymore (Figure 4 and Table 5).

Tetracalcium monocarboaluminate and $\mathrm{C}_{4} \mathrm{AH}_{13}$ present an unstable behaviour over time in mortars with MK, a fact which is attributed to the free portlandite in the system [30]. In de Silva and Glasser study [31] this behaviour was justified due to the reduction of the concentrations of $\mathrm{Ca}^{2+}$ and $\mathrm{OH}^{-}$ions in the pore solution at longer curing ages. 
Qualitatively a great similarity in mineralogical composition can be observed between the mortars in humid and marine curing. The main difference to the standard curing condition is the slower larnite hydration kinetics in the driest curing, which can justify the lower mechanical resistances observed in this curing condition.

In terms of the MK addition a fast development of the pozzolanic reaction was observed, clearly evident in the decrease and subsequent disappearance of portlandite with $\mathrm{MK}$ increment and with ageing.

In humid and marine curing conditions, the higher $\mathrm{RH}$ contact $(95 \pm 5 \%$ in humid curing and for marine curing in Table 4) and the moisture from the Atlantic ocean water spray benefits the hydration and pozzolanic reactions and the hydrated compounds formed, such as tetracalcium monocarboaluminate, tetracalcium aluminate hydrate and ettringite, which are relevant compounds for the development of mechanical resistances [32]. Another interesting feature with ageing is the increment of vaterite formation, which is related to dissolution/crystallization phenomenon as a result of the water action.

The MK addition increases the mechanical resistances as shown in Figure 3. This fact may be explained due to the appearance of hydrated compounds formed by pozzolanic reaction (Figures 4 and Table 5). In general a decrease in the CS values from 90 to 180 days can be observed, that can be justified by the instability of calciumaluminium hydrated compounds formed in the pozzolanic reaction. 

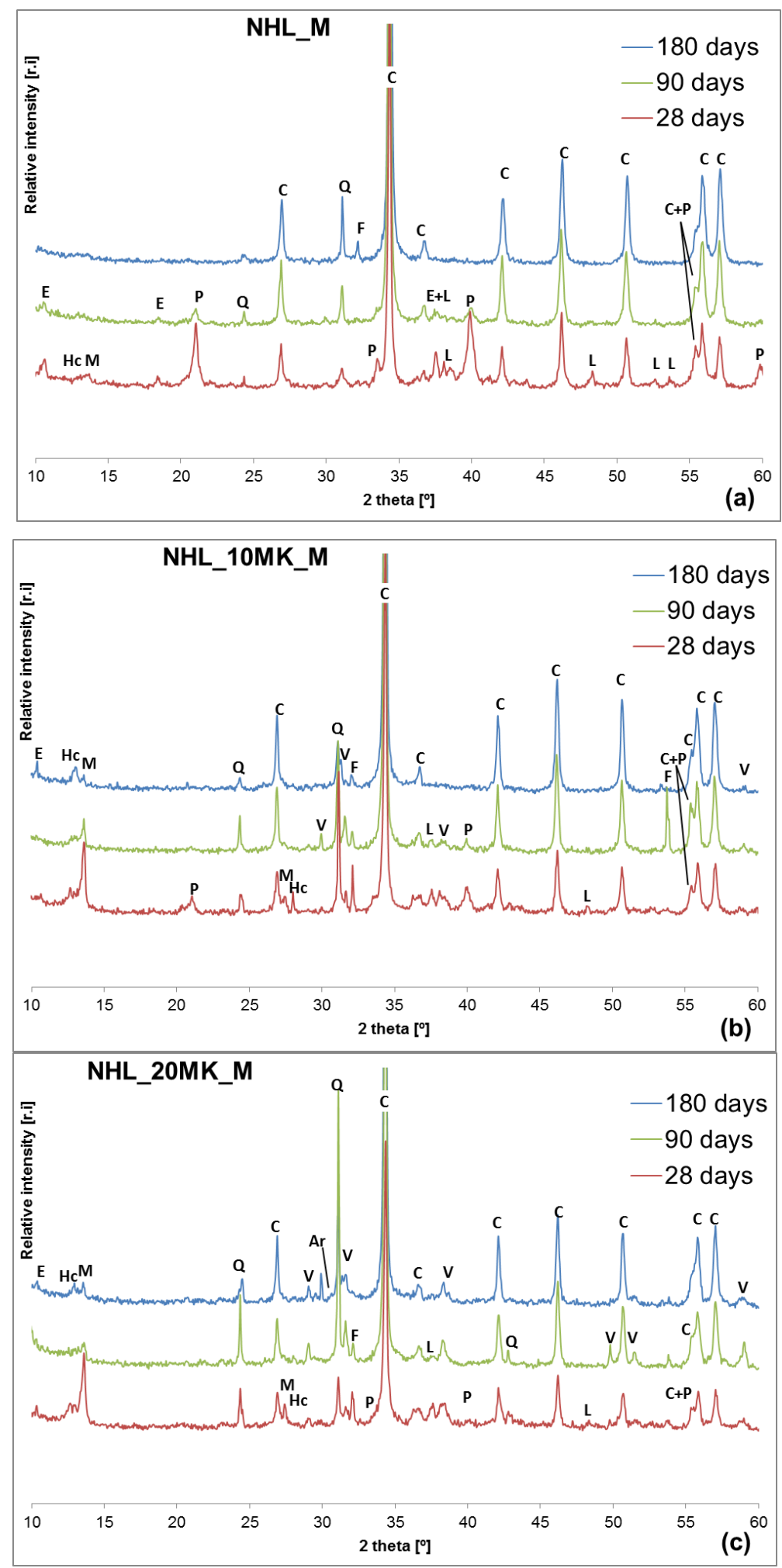

Fig. 4 - XRD patterns of (a) NHL, (b) NHL_10MK and (c) NHL_20MK mortars in marine curing. Notation: $\mathrm{P}-\mathrm{CH} ; \mathrm{C}-\mathrm{C} \overline{\mathrm{C}} ; \mathrm{L}-\mathrm{C}_{2} \mathrm{~S} ; \mathrm{E}-$ Ettringite;

$\mathrm{M}$ - Tetracalcium monocarboaluminate; $\mathrm{Hc}$ - Tetracalcium aluminate hydrate; $\mathrm{V}$ Vaterite; Ar - Aragonite; Q - Quartz. 
Grilo, J.; Santos Silva, A.; Faria, P.; Gameiro, A.; Veiga, R.; Velosa, A. Mechanical and mineralogical properties of natural hydraulic lime-metakaolin mortars in different curing conditions. Construction and Building Materials, v. 51, p. $287-294,2014$.

Table 5 - XRD composition of NHL mortars in all curing conditions at 28,90 and 180 days.

\begin{tabular}{|c|c|c|c|c|c|c|c|c|c|}
\hline \multirow{3}{*}{ Mineral phases } & \multicolumn{9}{|c|}{ Marine curing condition } \\
\hline & \multicolumn{3}{|c|}{ NHL } & \multicolumn{3}{|c|}{ NHL_10MK } & \multicolumn{3}{|c|}{ NHL_20MK } \\
\hline & 28 days & 90 days & 180 days & 28 days & 90 days & 180 days & 28 days & 90 days & 180 days \\
\hline Calcite & +++ & $+++/++++$ & $+++/++++$ & +++ & $+++/++++$ & $+++/++++$ & +++ & $+++/++++$ & $++/+++$ \\
\hline Vaterite & - & - & - & + & $\operatorname{tr}$ & $?$ & + & $+/++$ & $+/++$ \\
\hline Aragonite & - & - & - & - & - & - & - & - & - \\
\hline Portlandite & ++ & + & - & + & - & - & - & - & - \\
\hline $\begin{array}{c}\text { Tetracalcium } \\
\text { monocarboaluminate }\end{array}$ & $\operatorname{tr}$ & - & - & $+/++$ & + & $\operatorname{tr}$ & $+/++$ & $\operatorname{tr}$ & $\operatorname{tr}$ \\
\hline Ettringite & $\operatorname{tr}$ & $\operatorname{tr}$ & - & $?$ & $?$ & $\operatorname{tr}$ & $?$ & $?$ & $?$ \\
\hline Hidrocalumite & $\operatorname{tr}$ & $\operatorname{tr}$ & $\operatorname{tr}$ & + & $\operatorname{tr}$ & $\operatorname{tr}$ & + & + & + \\
\hline Larnite & + & $\operatorname{tr}$ & - & $\operatorname{tr}$ & $?$ & - & $\operatorname{tr}$ & - & - \\
\hline Quartz & $\operatorname{tr}$ & + & + & $+/++$ & $+/++$ & + & + & ++ & + \\
\hline Feldspar & - & - & $\operatorname{tr}$ & + & + & - & + & + & + \\
\hline \multicolumn{10}{|c|}{ Humid curing condition } \\
\hline Calcite & +++ & +++ & $+++/++++$ & +++ & $\mid+++/++++$ & $+++/++++$ & +++ & \begin{tabular}{|l|}
$+++/++++$ \\
\end{tabular} & $++/+++$ \\
\hline Vaterite & - & - & - & + & $+/++$ & ++ & + & $+/++$ & ++ \\
\hline Aragonite & - & - & - & - & - & - & - & $\operatorname{tr}$ & $\operatorname{tr}$ \\
\hline Portlandite & $++/+++$ & ++ & + & + & $\operatorname{tr}$ & $\operatorname{tr}$ & $?$ & - & - \\
\hline $\begin{array}{c}\text { Tetracalcium } \\
\text { monocarboaluminate }\end{array}$ & $\operatorname{tr}$ & $\operatorname{tr}$ & $\operatorname{tr}$ & $+/++$ & + & + & $+/++$ & $+/++$ & + \\
\hline Ettringite & $\operatorname{tr}$ & $\operatorname{tr}$ & $\operatorname{tr}$ & $\operatorname{tr}$ & $\operatorname{tr}$ & $\operatorname{tr}$ & $?$ & $?$ & $\operatorname{tr}$ \\
\hline Hidrocalumite & $\operatorname{tr}$ & $\operatorname{tr}$ & $\operatorname{tr}$ & $\operatorname{tr} /+$ & $\operatorname{tr}$ & $\operatorname{tr}$ & + & $?$ & $?$ \\
\hline Larnite & + & $\mathrm{tr} /+$ & $\operatorname{tr}$ & $\mathrm{tr} /+$ & $\operatorname{tr}$ & $\operatorname{tr}$ & + & $\operatorname{tr}$ & $?$ \\
\hline Quartz & + & $+/++$ & + & + & $+/++$ & + & + & $+/++$ & + \\
\hline Feldspar & $\operatorname{tr}$ & + & $\operatorname{tr}$ & $\operatorname{tr}$ & + & $\operatorname{tr}$ & + & + & $\operatorname{tr}$ \\
\hline \multicolumn{10}{|c|}{ Standard curing condition } \\
\hline Calcite & +++ & $+++/+++$ & $+++/++++$ & +++ & +++ & $+++/+++$ & +++ & $+++/++++$ & $++/+++$ \\
\hline Vaterite & - & - & - & $\operatorname{tr} /+$ & $\operatorname{tr} /+$ & + & + & + & + \\
\hline Aragonite & - & - & - & - & - & - & - & $\operatorname{tr}$ & $\operatorname{tr}$ \\
\hline Portlandite & ++ & $\operatorname{tr} /+$ & $\operatorname{tr} /+$ & + & $?$ & - & - & - & - \\
\hline $\begin{array}{c}\text { Tetracalcium } \\
\text { monocarboaluminate }\end{array}$ & $\operatorname{tr}$ & $?$ & - & + & $\operatorname{tr} /+$ & $\operatorname{tr}$ & $+/++$ & + & + \\
\hline Ettringite & $\operatorname{tr}$ & $?$ & - & - & $\operatorname{tr}$ & $?$ & $?$ & $?$ & $\operatorname{tr}$ \\
\hline Hidrocalumite & $\operatorname{tr}$ & $?$ & - & $\operatorname{tr} /+$ & $?$ & - & + & $\operatorname{tr}$ & $?$ \\
\hline Larnite & + & $\mathrm{tr} /+$ & $\operatorname{tr} /+$ & + & $\mathrm{tr} /+$ & $\operatorname{tr} /+$ & + & $\operatorname{tr}$ & $\operatorname{tr}$ \\
\hline Quartz & $\operatorname{tr}$ & + & $\operatorname{tr}$ & + & ++ & ++ & $+/++$ & $+/++$ & + \\
\hline Feldspar & - & $\operatorname{tr}$ & - & $\operatorname{tr}$ & $\operatorname{tr}$ & $+/++$ & $\operatorname{tr}$ & $\operatorname{tr}$ & $\operatorname{tr}$ \\
\hline
\end{tabular}

Notation: - = undetected; ? = doubts in presence; $\operatorname{tr}=$ traces; + = low proportion;

$++=$ medium proportion; +++ = high proportion; ++++ = predominant compound . 


\subsection{TG-DTA results}

Table 6 presents the TG-DTA results obtained for all mortars in three different curing conditions. For a representative purpose, Figure 5 presents the dTG pattern of mortars cured in marine curing condition. The dTG patterns were chosen since the start point and end of the mass losses are more perceptible. These patterns showed 3 main mass losses, respectively from $\mathrm{T}_{\text {ambient }}-380^{\circ} \mathrm{C}, 380-500^{\circ} \mathrm{C}$ and $500-850^{\circ} \mathrm{C}$, which correspond, according to the XRD analysis, to the pozzolanic and hydration products dehydration $\left(\mathrm{HP}_{\mathrm{DH}}\right)$, portlandite dehydration $\left(\mathrm{P}_{\mathrm{DH}}\right)$ and the carbonates decomposition $\left(C_{D C}\right)$, respectively. In the first mass loss region the $\mathrm{CSH}$ dehydration must be also considered $[30,33,34]$.

In general, the dTG results corroborate the XRD analysis.

Table 6 - Mass losses (wt \%) obtained by TG-DTA analysis.

\begin{tabular}{|c|c|c|c|c|c|c|c|c|c|}
\hline \multirow{2}{*}{$\begin{array}{c}\text { Samples } \\
\text { identification }\end{array}$} & \multicolumn{9}{|c|}{ Temperature range } \\
\cline { 2 - 10 } & \multicolumn{3}{|c|}{$\mathbf{T}_{\text {amb }} \mathbf{- 3 8 0 ^ { \circ } \mathbf { C }}$} & \multicolumn{3}{c|}{$\mathbf{3 8 0 - 5 0 0 ^ { \circ } \mathbf { C }}$} & \multicolumn{3}{c|}{$\mathbf{5 0 0 - 8 5 0 ^ { \circ } \mathbf { C }}$} \\
\cline { 2 - 10 } & $\mathbf{2 8}$ days & $\mathbf{9 0}$ days & $\mathbf{1 8 0}$ days & $\mathbf{2 8}$ days & $\mathbf{9 0}$ days & $\mathbf{1 8 0}$ days & $\mathbf{2 8}$ days & $\mathbf{9 0}$ days & $\mathbf{1 8 0}$ days \\
\hline NHL_M & 1.07 & 0.80 & 1.00 & 0.57 & 0.31 & 0.00 & 3.63 & 5.40 & 6.10 \\
\hline NHL_H & 1.01 & 1.20 & 1.00 & 0.44 & 0.51 & 0.00 & 4.23 & 5.50 & 6.30 \\
\hline NHL_S & 0.81 & 0.92 & 0.80 & 0.28 & 0.30 & 0.00 & 4.05 & 5.80 & 5.40 \\
\hline NHL_10MK_M & 1.67 & 1.60 & 1.40 & 0.28 & 0.00 & 0.00 & 3.00 & 4.60 & 5.50 \\
\hline NHL_10MK_H & 1.87 & 1.80 & 1.50 & 0.42 & 0.00 & 0.00 & 2.67 & 4.80 & 4.52 \\
\hline NHL_10MK_S & 1.85 & 1.70 & 1.30 & 0.18 & 0.00 & 0.00 & 2.51 & 5.60 & 4.90 \\
\hline NHL_20MK_M & 2.19 & 1.50 & 1.70 & 0.00 & 0.00 & 0.00 & 2.80 & 4.41 & 4.91 \\
\hline NHL_20MK_H & 2.28 & 2.20 & 1.60 & 0.00 & 0.00 & 0.00 & 1.88 & 2.81 & 4.80 \\
\hline NHL_20MK_S & 1.71 & 2.11 & 1.60 & 0.00 & 0.00 & 0.00 & 2.07 & 4.50 & 4.31 \\
\hline
\end{tabular}




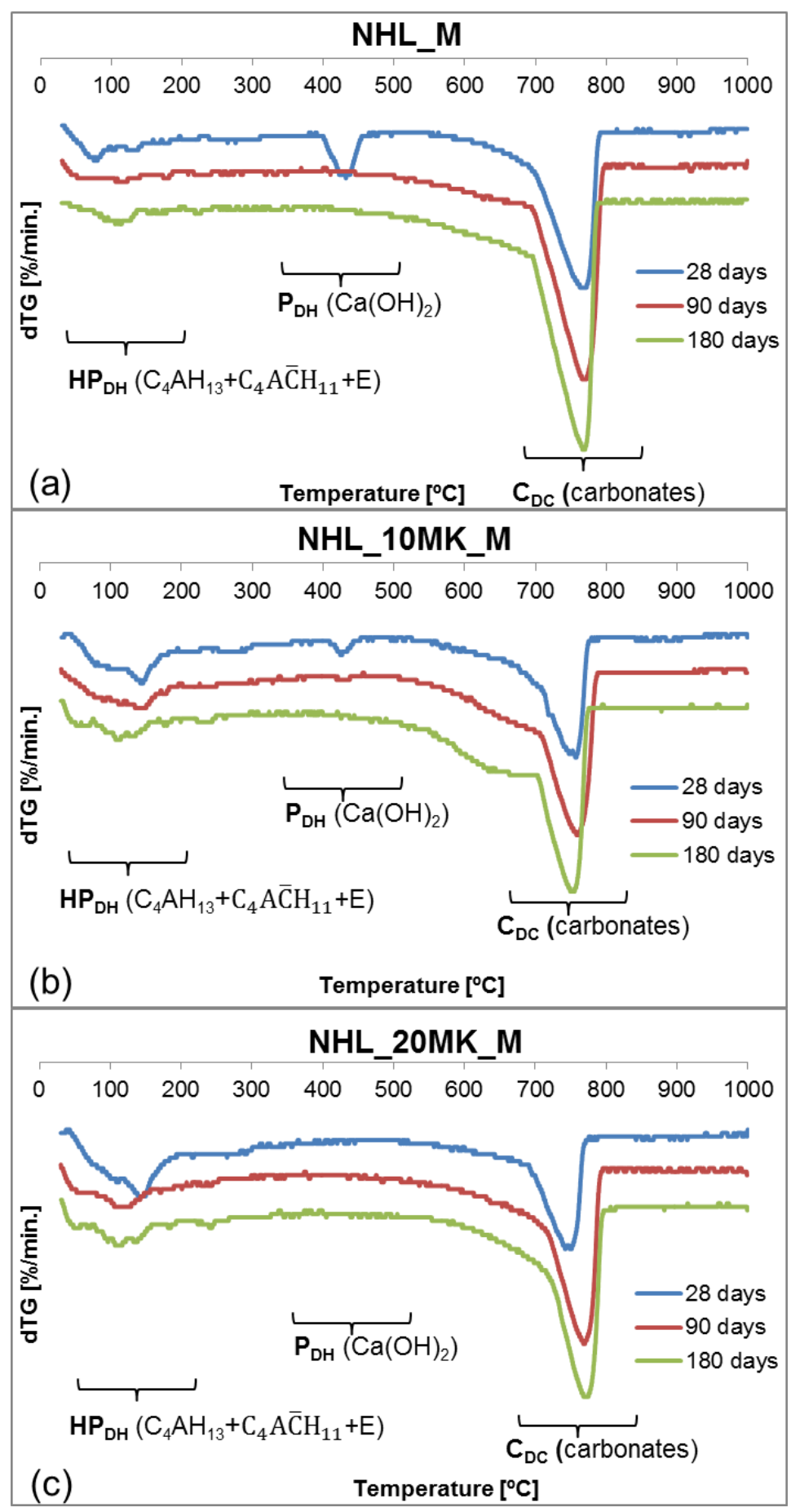

Fig. 5 - dTG charts of (a) NHL, (b) NHL_10MK and (c) NHL_20MK mortars in the marine curing, showing the characteristic regions for pozzolanic and hydration products dehydration - $\mathrm{HP}_{\mathrm{DH}}$-, portlandite dehydration - $\mathrm{P}_{\mathrm{DH}}$ - and the carbonates decompostion $-C_{D C}$. 
The main difference between all mortars is the inexistence of the portlandite peak in NHL_20MK mortars, which implies that portlandite was totally consumed in pozzolanic and carbonation reactions.

With ageing it is observed that in mortars with MK, there is a decrease with time (28 to $180 \mathrm{~d}$ ) in pozzolanic dehydration region, which can be attributed to the instability of calcium-aluminum hydrated compounds, as seen in section 5.2 .

To evaluate the hardening reactions with ageing and curing type, the portlandite consumption in carbonation reaction and in pozzolanic reactions was determined using the mass losses (ML) obtained by TG-DTA analysis. The portlandite and carbonate contents present in the lime $\left(\mathrm{CHf}_{\text {lime }}\right.$ and $\left.\mathrm{CC}_{\text {lime }}\right)$ were both computed in the hydration and carbonation mortars' evolution. The following equations explain the different steps considered in the calculations at a certain curing age, bearing in mind that the hydration kinetics are the same in all mortars with identical curing conditions:

1) Mortars without MK:

$$
\begin{array}{ll}
\mathrm{CH}_{\text {free }}=\mathrm{ML}_{\left(380-500^{\circ} \mathrm{C}\right)} \times \mathrm{k}_{1} & \text { [Equation 3] } \\
\mathrm{CC}_{\text {mortar }}=\mathrm{ML}_{\left(500-850^{\circ} \mathrm{C}\right)} \times \mathrm{k}_{2}-\left(\mathrm{CC}_{\text {lime }} \times \% \text { Lime }\right) & \text { [Equation 4] } \\
\mathrm{CH}_{\text {carb }}=\mathrm{CC}_{\text {mortar }} \times \mathrm{k}_{3} & \text { [Equation 5] } \\
\mathrm{CH}_{\text {mortar }}=\mathrm{CH}_{\text {carb }}+\mathrm{CH}_{\text {free }} & \text { [Equation 6] } \\
\mathrm{T}_{\text {carb }}=\left(\mathrm{CH}_{\text {carb }} / \mathrm{CH}_{\text {mortar }}\right) \times 100 & \text { [Equation 7] } \\
\mathrm{T}_{\text {free }}=\left(\mathrm{CH}_{\text {free }} / \mathrm{CH}_{\text {mortar }}\right) \times 100 & \text { [Equation 8] } \\
\mathrm{CH}_{\text {hidr NHL }}=\mathrm{CH}_{\text {mortar }}-\left(\mathrm{CHf}_{\text {lime }} \times \% \text { Lime }\right) & \text { [Equation 9] } \\
\mathrm{T}_{\text {hidr NHL }}=\left(\mathrm{CH}_{\text {hidr NHL }} / \mathrm{CH}_{\text {mortar }}\right) \times 100 & \text { [Equation 10] }
\end{array}
$$

2) For mortars with MK equations 3 to 9 and:

$$
\begin{array}{ll}
\mathrm{CH}_{\text {hidr MK }}=\mathrm{CH}_{\text {hidr NHL }} \times \% \mathrm{MK} & \text { [Equation 11] } \\
\mathrm{CH}_{\mathrm{poz}}=\left[\left(\mathrm{CHf}_{\text {lime }} \times \% \text { Lime }\right)+\mathrm{CH}_{\text {hidr NHL }}-\mathrm{CH}_{\text {mortar }}\right. & \text { [Equation 12] } \\
\mathrm{T}_{\mathrm{poz}}=\left(\mathrm{CH}_{\mathrm{poz}} / \mathrm{CH}_{\text {mortar }}\right) \times 100 & \text { [Equation 13] } \\
\mathrm{T}_{\text {hidr MK }}=\left(\mathrm{CH}_{\text {hidr MK }} / \mathrm{CH}_{\text {mortar }}\right) \times 100 & \text { [Equation 14] }
\end{array}
$$


The meaning of abbreviation used is as follows:

$\mathrm{k}_{1}, \mathrm{k}_{2}$ (same as previously described in section 2.) and $\mathrm{k}_{3}$, the molar masses quotients, $\mathrm{k}_{1}=\mathrm{MM}\left(\mathrm{Ca}(\mathrm{OH})_{2}\right) / \mathrm{MM}\left(\mathrm{H}_{2} \mathrm{O}\right)$;

$\mathrm{k}_{2}=\mathrm{MM}\left(\mathrm{CaCO}_{3}\right) / \mathrm{MM}\left(\mathrm{CO}_{2}\right)$;

$\mathrm{k}_{3}=\mathrm{MM}\left(\mathrm{Ca}(\mathrm{OH})_{2}\right) / \mathrm{MM}\left(\mathrm{CaCO}_{3}\right)$;

$\mathrm{CH}_{\text {free }}-$ free portlandite content of the mortar;

$\mathrm{CC}_{\text {mortar }}$ - calcite content of the mortar;

\%Lime - lime content (wt. \%) in mortars;

$\mathrm{CH}_{\text {carb }}$ - portlandite consumed in carbonation reaction;

$\mathrm{CH}_{\text {mortar }}$ - total portlandite present of the mortar;

$\mathrm{CH}_{\text {hidr NHL }}$ - portlandite content produced in hydration of $\mathrm{NHL}$;

$\mathrm{CH}_{\text {hidr } \mathrm{MK}}$ - portlandite content produced in hydration reaction in mortars with $\mathrm{MK}$ content;

$\mathrm{CH}_{\mathrm{poz}}$ - lime consumed in pozzolanic reaction;

$\mathrm{T}_{\text {free }}-$ relative free portlandite content;

$\mathrm{T}_{\text {carb }}$ - relative portlandite content consumed in carbonation reaction.

$\mathrm{T}_{\mathrm{poz}}$ - relative portlandite content consumed in pozzolanic reaction.

$\mathrm{T}_{\text {hidr NHL }}$ - relative portlandite content produced in hydration reaction in NHL mortars.

$\mathrm{T}_{\text {hidr } \mathrm{MK}}$ - relative portlandite content produced in hydration reaction in NHL-MK mortars.

Figures 6 and 7 present the portlandite consumption and free portlandite available to react with ageing in the different curing conditions.

From the analysis of results, it is possible to verify that portlandite is mainly consumed in the carbonation reaction. This reaction increases with curing time, being almost completed at 180 days in all curing conditions and its rate is higher in the standard curing condition. However, in the first 90 days some portlandite was also consumed in the pozzolanic reaction, being this consumption higher in humid and standard curing conditions. According to Table 4, during the first two months the mean 
$\mathrm{RH}$ at marine humid conditions was not high (lower than at humid curing conditions), maybe explaining the absence of not so high consumption.

From figure 7 it can be noticed that the content of free portlandite is higher in mortars placed in marine and humid curing regimes. This result can be explained by a higher hydration (Figure 8) and lower carbonation rates in these two curing conditions.

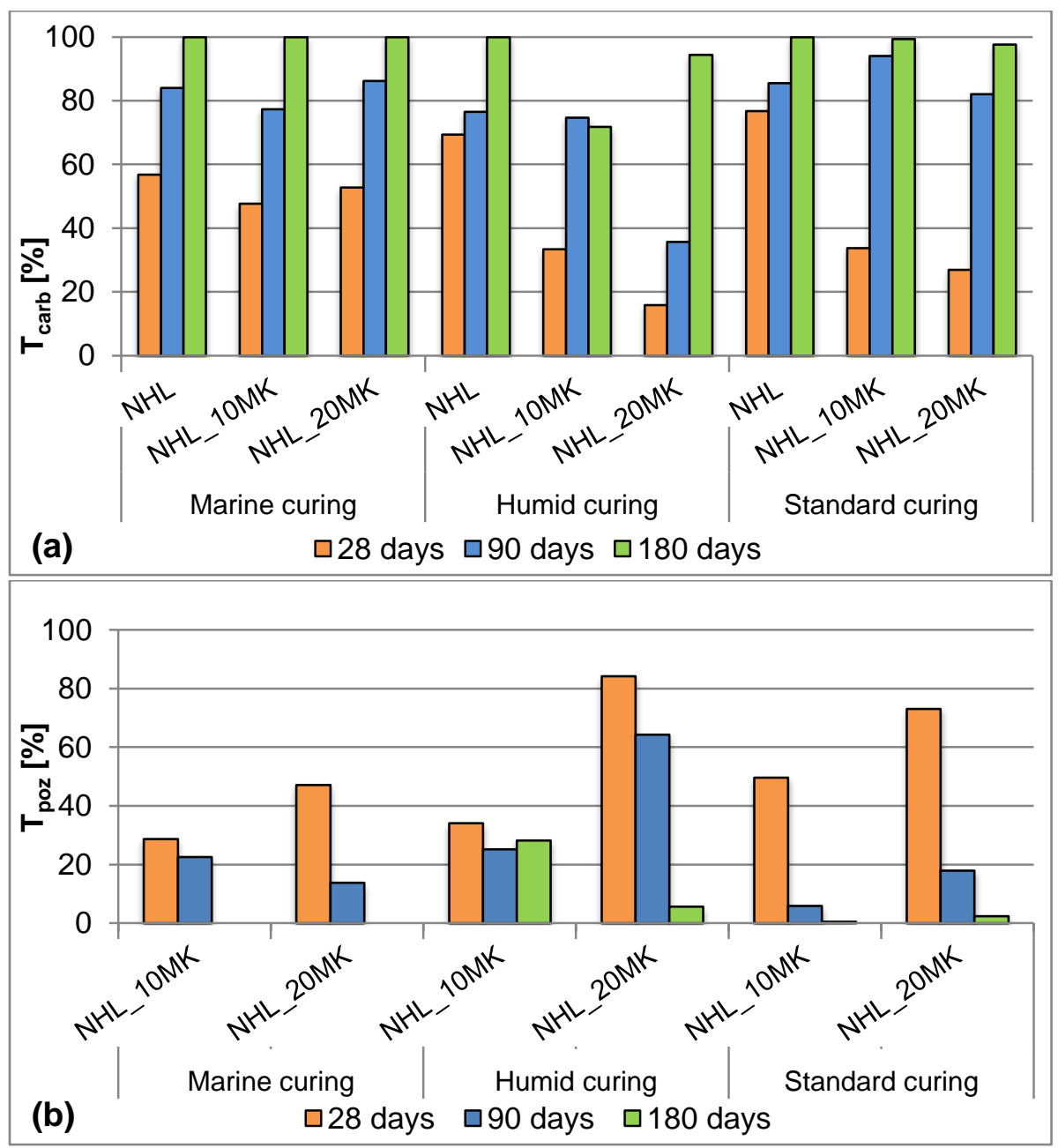

Fig. 6 - Relative portlandite consumed (in \%) in (a) the carbonation reaction ( $\left.\mathrm{T}_{\text {carb }}\right)$ and in (b) the pozzolanic reaction ( $\left.T_{\mathrm{poz}}\right)$. 


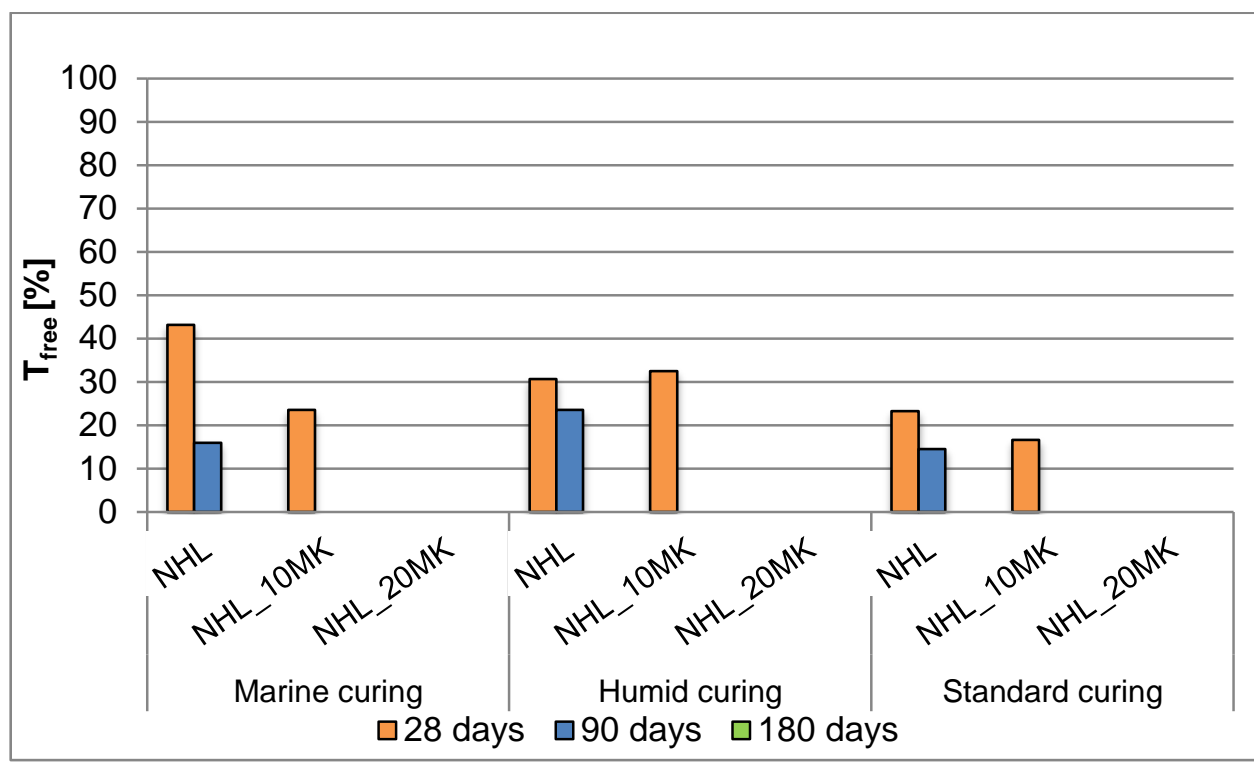

Fig. 7 - Relative free portlandite content ( $T_{\text {free }}$, in \%).

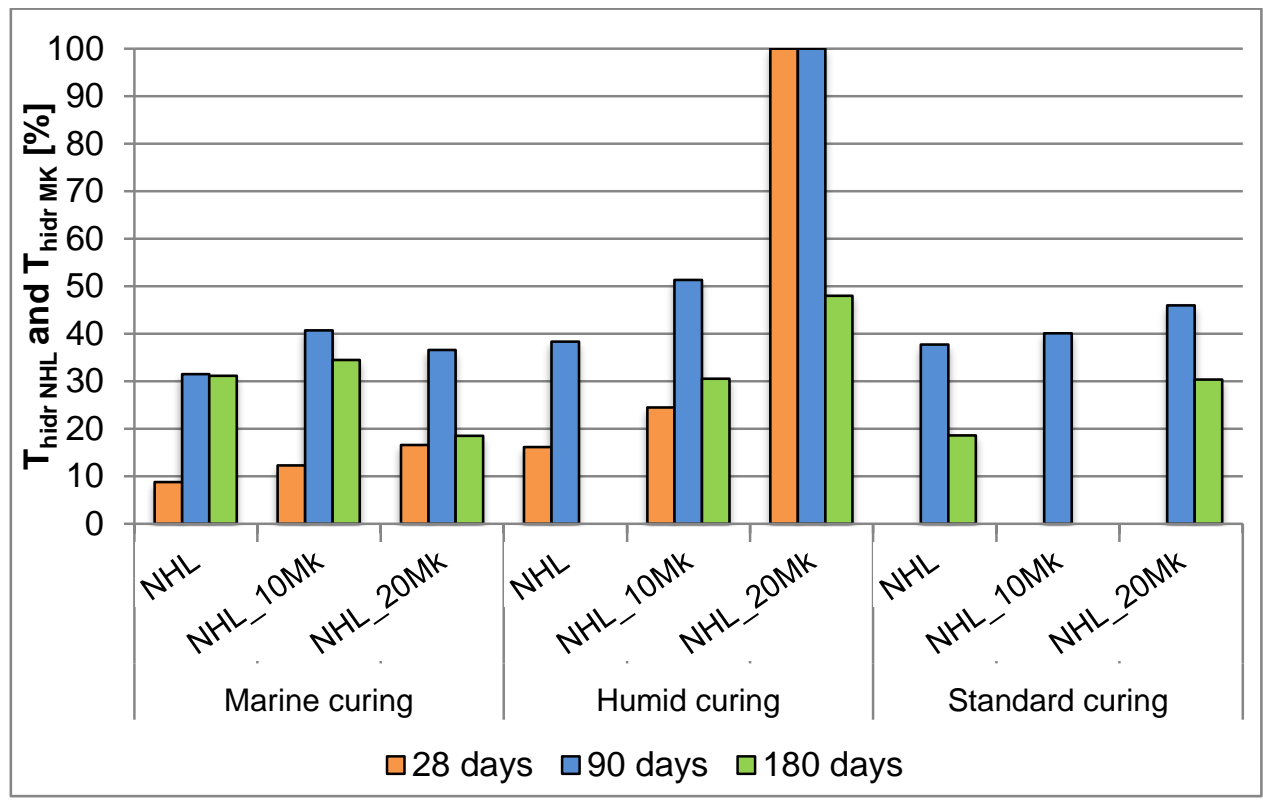

Fig. 8 - Relative portlandite content ( $\mathrm{T}_{\text {hidr } \mathrm{NHL}}$ and $\mathrm{T}_{\text {hidr MK }}$ in \%) produced in hydration reaction.

\subsection{Global discussion}

According to these findings, and comparing to the mechanical results, it can be observed that the pozzolanic reaction is the main factor in terms of influencing strengths improvements, especially those obtained at 28 days. 
Grilo, J.; Santos Silva, A.; Faria, P.; Gameiro, A.; Veiga, R.; Velosa, A. Mechanical and mineralogical properties of natural hydraulic lime-metakaolin mortars in different curing conditions. Construction and Building Materials, v. 51, p. 287-294, 2014.

In terms of curing conditions it can be noticed that humid and marine curing present the higher mechanical test results, being this observation mainly related to the kinetics of hydration and pozzolanic reactions in both humid environments.

The decrease of mechanical results with ageing in mortars with MK, which was related to the instability of the pozzolanic calcium-aluminum hydrated compounds formed, can also be justified by the kinetics of the NHL-MK reaction, that is mainly developed at very early ages [30].

\section{Conclusions}

From mineralogical and mechanical strength results obtained, the main conclusions extracted are:

- NHL mortars cured in controlled humidity conditions or in natural marine environment present similar behaviour in terms of mechanical and mineralogical results, and differ from the same mortars cured in standard $\mathrm{RH}$ conditions. It must be reminded that the natural exterior exposure of the mortar samples went on in Portugal from February to July, having a degree of moisture in average higher than in standard curing condition, fact that might have created similar conditions to those of laboratory humid curing and favoured hydration and carbonation of $\mathrm{NHL}$ mortars.

- The addition of MK to NHL mortars improves its strength characteristics, being these improvements higher with controlled humid curing conditions. These improvements may be unnecessary for mortars to be applied as renders or plasters on old masonry but may be adequate for mortars with higher strength requirements.

- $\mathrm{NHL}$ mortars with and without MK present different strength rates with curing age. Contrary to NHL mortars, NHL-MK mortars sometimes present a decrease of strength with ageing, being this decrease related to the instability of the pozzolanic compounds formed. 
- The main hardening reaction in $\mathrm{NHL}$ mortars, with or without $\mathrm{MK}$, is carbonation. However, hydraulic compounds are also formed, especially in mortars with MK and in early ages (28 days), which increase the mechanical strength and should improve the resistance to water action.

- The mechanical results of the mortars in marine curing suggest that these mortars should be suitable and adequate to be applied in building masonries placed near marine environments.

\section{Acknowledgements}

The authors wish to acknowledge the Fundação para a Ciência e Tecnologia (FCT) for the financial support under project METACAL (PTDC/ECM/100431/2008) and to the companies SECIL and IMERYS for the supply of NHL3,5 and metakaolin used in this work.

\section{References}

1. Velosa AL, Veiga MR, Coroado J, Ferreira VM, Rocha F. Characterization of ancient pozzolanic mortars from Roman times to the 19th century: Compatibility issues of new mortars with substrates and ancient mortars. In: M. Bostenaru Dan, R. Prikryl, A. Török (Eds.), Materials, Technologies and Practice in Historic Heritage Structures, Hardcover. ISBN: 978-90-481-2683-5; 2009, Part III, chapter 13, p. 235-255.

2. Velosa A, Coroado J, Veiga MR, Rocha F. Characterisation of roman mortars from Conímbriga with respect to their repair. Mater. Charact. 2007; 58(11-12 Spec. issue): $1208-1216$.

3. Charola A, Faria-Rodrigues P, McGhie AR, Henriques FMA. Pozzolanic components in lime mortars: correlating behaviour, composition and microstructure. Int. J. Restor. Build. Monum. 2005; 11(2):111-118.

4. Mosquera MJ, Silva B, Prieto B, Ruiz-Herrera E. Addition of cement to limebased mortars: Effect on pore structure and vapor transport. Cem. Concr. Res. 2006; 36:1635-1642.

5. Veiga MR, Fragata A, Velosa AL, Magalhães AC, Margalha G. Lime-based mortars: viability for use as substitution renders in historical buildings, Int. J. Archit. Herit. 2010; 4(2):177-195. 
6. Sabbioni C, Zappia G, Riontino C, Aguilera J, Puertas F, Van Balen K, Toumbakari EE. Atmospheric deterioration of ancient and modern hydraulic mortar. Atmos. Environ. 2001; 35:539-548.

7. Martínez-Ramírez S, Puertas F, Blanco-Varela M. Carbonation process and properties of new lime mortar with added sepiolite. Cem. Concr. Res. 1995; 25(1):39-50.

8. Faria P, Henriques FMA, Rato V, Comparative evaluation of lime mortars for architectural conservation. J. Cult. Herit. 2008; 9(3):338-346.

9. El-Turki A, Ball RJ, Carter MA, Wilson MA, Ince C, Allen GC. Effect of dewatering on the strength of lime and cement mortars. J. Am. Ceram. Soc. 2010; 2081:2074-2081.

10. CEN. EN 459-1:2010. Building lime. Part 1: Definitions, specifications and conformity criteria. Brussels; 2010.

11. Gulotta D, Goidanich S, Tedeschi C, Nijland TG, Toniolo L. Commercial NHLcontaining mortars for the preservation of historical architecture. Part 1: Compositional and mechanical characterization. Constr. Build. Mater. 2013; 38:31-42.

12. El-Turki A, Ball RJ, Allen GC. The influence of relative humidity on structural and chemical changes during carbonation of hydraulic lime. Cem. Concr. Res. 2007; 37(8):1233-1240.

13. Allen GC, Ball RJ. Mechanical Properties of Hydraulic Lime Mortars. In: Portuguese Association of Construction Mortar (APFAC), $4^{\text {th }}$ Portuguese Conference on Mortars and ETICS (CD-ROM), Lisbon, 2012.

14. Lanas J, Pérez Bernal JL, Bello MA, Alvarez Galindo Jl. Mechanical properties of natural hydraulic lime-based mortars. Cem. Concr. Res. 2004; 34(12):21912201.

15. Faria-Rodrigues P. Resistance to salts of lime and pozzolan mortars. In: RILEM Proceedings pro 067 - International RILEM Workshop on Repair Mortars for Historic Masonry, C.Groot (Ed.), RILEM Publications on-line, 2009, 99-110.

16. Siddique R, Klaus J, Influence of metakaolin on the properties of mortar and concrete: A review. Appl. Clay Sci. 2009; 43(3-4):392-400.

17. Said-Mansour M, Kadri EH, Kenai S, Ghrici M, Bennaceur R. Influence of calcined kaolin on mortar properties. Constr. Build. Mater. 2011; 25(5):22752282.

18. Donatello S, Tyrer M, Cheeseman CR. Comparison of test methods to assess pozzolanic activity. Cem. Concr. Comp. 2010; 32(2):121-127. 
19. Cizer O. Competition between carbonation and hydration on the hardening of calcium hydroxide and calcium silicate binders. $\mathrm{PhD}$ thesis. University of Leuven; 2009.

20. El-Turki A, Ball R, Holmes S, Allen W, Allen G. Environmental cycling and laboratorial testing to evaluate the significance of moisture control for lime mortars. Constr. Build. Mater. 2010; 24:1392-1397.

21. Faria P, Martins A. Influence of cure conditions on lime and lime-metakaolin mortars. In: Proceedings of the XII DBMC $-12^{\text {th }}$ International Conference on Durability of Building Materials and Components, V.P Freitas, H. Corvacho, M.Lacasse (eds.) Vol.2, 2011, p. 713-720.

22. Grilo J, Faria P, Santos-Silva A, Silva V, Veiga R, Velosa A. New Natural Hydraulic Lime mortars - Physical and microstructural properties in different curing conditions, Constr. Build. Mater. 2013 (under review).

23. CEN. EN 1097-3:1998. Tests for mechanical and physical properties of aggregates - Part 3: Determination of loose bulk density and voids; 1998.

24. AFNOR. NFP 18-513:2012. Pozzolanic addition for concrete - Metakaolin Definitions, specifications and conformity criteria (in French); 2012.

25. Pontes J, Santos-Silva A, Faria P. Evaluation of pozzolanic reactivity of artificial pozzolans. Mater. Sci. Forum, 2012; 730-732:433-438.

26. CEN. EN 1015-2:1998/A1:2006. Methods of test for mortar for masonry. Part 2: Bulk sampling of mortars and preparation of test mortars; 2006.

27. CEN. EN 1015-3:1999/A2:2006. Methods of test for mortar for masonry. Part 3: Determination of consistency of fresh mortar (by flow table); 2006.

28. CEN. EN 1015-11:1999/A1:2006. Methods of test for mortars for masonry. Part 11: Determination of flexural and compressive strength of hardened mortar; 2006.

29. Nehrke G, Van Cappellen P, Van der Weijden CH. Framboidal vaterite aggregates and their transformation into calcite: $A$ morphological study, J. Cryst. Growth. 2006; 287:528 - 530.

30. Gameiro A, Santos-Silva A, Veiga R, Velosa A. Hydration products of limemetakaolin pastes at ambient temperature with ageing. Thermochim. Acta. 2012a; 535:36-41.

31. De Silva PS, Glasser FG. Hydration of cements based on MK. Thermochemistry. Adv. Cem. Res. 1992; 4(16):167-178.

32. Borges C, Santos-Silva A, Borsoi G. Historical Heritage: A Study to Conservation. Mater. Sci. Forum. 2012; 730-732:604-610. 
Grilo, J.; Santos Silva, A.; Faria, P.; Gameiro, A.; Veiga, R.; Velosa, A. Mechanical and mineralogical properties of natural hydraulic lime-metakaolin mortars in different curing conditions. Construction and Building Materials, v. 51, p. $287-294,2014$.

33. Bakolas A, Aggelakopoulou E, Moropoulou A, Anagnostopoulou S. Evaluation of pozzolanic activity and physico-mechanical characteristics in metakaolin-lime pastes. J. Therm. Anal. Calorim. 2006; 84:157-163.

34. Gameiro A, Santos-Silva A, Veiga MR, Velosa AL. Phase and microstructural characterization of lime-MK blended mixes. Mater. Sci. Forum. 2012; 730732:135-140. 